Review Article

\title{
Microbe-Assisted Biodegradation, Bioremediation and Metabolic Engineering
}

\author{
HEMANT J PUROHIT ${ }^{1, *}$, S DAYANANDA ${ }^{2}$ and PHALE PRASHANT ${ }^{3}$ \\ ${ }^{1}$ Environmental Biotechnology \& Genomics Division, CSIR-National Environmental Engineering Research \\ Institute, Nagpur \\ ${ }^{2}$ School of Life Sciences, University of Hyderabad, Hyderabad, India \\ ${ }^{3}$ Department of Biosciences and Bioengineering, IIT-Bombay, Powai, Mumbai, India
}

(Received on 03 April 2019; Accepted on 05 November 2019)

\begin{abstract}
We summarize here the recent research and development in the area of microbe assisted biodegradation and remediation processes by different research lab in the country. The various substituted hydrocarbons as pollutants have been studied by different groups. The depth of the study includes the characterization of key bacterial metabolic pathway for target pollutants through both genome and proteome levels. By understanding the pathway, in few cases the metabolic engineering approached have been demonstrated for the efficient utilization of pollutants. The better understanding to key enzyme were explored using protein modeling or by understanding its expression through heterologous host. The review also presents few case studies where pilot scale demonstration of contaminated sites with selected pollutants, have also been carried out effectively.
\end{abstract}

Keywords: Biodegradation, Bioremediation; Metabolic Engineering

\section{Introduction}

A wide range of aromatic compounds including solvents are being used in industries for the production of pesticides, dyes, plasticizer, paints, textiles, etc. The impact of these pollutants is very serious as these are capable of inducing endocrine disruption, genotoxic, mutagenic and carcinogenic effect on human health. The effects are more alarming due to long term persistence of these pollutants in the environment. Therefore, to overcome the effects, it is essential to remediate these compounds. The aromatics in the environment are eliminated by processes like volatilization, photooxidation, chemical oxidation, adsorption to soil matrix or biodegradation by microorganisms (bioremediation). Bioremediation is an environmentally "green" method of using microbes - either naturally-occurring or introduced (in naturallyoccurring form or engineered) - to break down pollutants to non- toxic substances. Bioremediation can be in situ or ex situ. The biological processes for treating toxic pollutants are gaining interest over chemical and physical methods especially in terms of economic and environmental development; where instead of toxic by-products generated under nonbiological methods, biological processes produce useful and relatively less toxic intermediates that enter the biogeochemical cycles. Bioremediation not only serves removal of contaminants but also has other positive aspects including enhancement of the soil quality, waste water treatment, carbon sequestration etc. However, bioremediation also encounters some limitations viz. toxicity of the compound, presence of simpler carbon source, salinity and other stressors. There are number of research groups working in the area of bioremediation and environmental engineering, which will help to clean up the environment. This report gives the recent advances in the field of microbe-assisted biodegradation and bioremediation and metabolic engineering in the country. 


\section{Microbe-Assisted Biodegradation and Bioremediation}

Some of the reported bioremediation technologies include natural attenuation, bioaugmentation, bioleaching, bioreactor, biostimulation, electro-kinetic mediated bioremediation and phytoremediation (Paliwal et al., 2012, Pinjari et al., 2013, Kundu et al., 2014, Reddy et al., 2016, Chatterjee et al., 2017, Juwarkar 2012). The starting point for any bioremediation activity is the assessment of the inherent microflora at a contaminated niche. Based on their catabolic capacities, remediation processes can be designed. A large number of bacteria including Pseudomonas, Alcaligens, Sphingomonas, Stenotrophomonas, Rhodococcus, Bacillus (Qureshi et al., 2007, Tripathi et al., 2011, Verma et al., 2011, Sreenivasulu et al., 2012, Ghosh et al., 2017 ) etc. have been reported for bioremediation of various contaminated sites.

One strategy of bioremediation is phytoremediation that involves plant-microbe interaction and by which sustainable growth of plants in the contaminated sites could be restored. Microbes-soilplant interactions for in-situ treatment of pollutants in contaminated sites have been reported as MicrobeAssisted-Phytoremediation (MAP) technology (Juwarkar, 2012). MAP technology has been reported to be ecofriendly, economic and effective for restoration of degraded land such as mines, spoil dumps (Juwarkar, 2012). The report has also illustrated the application of MAP technologies at sites where shallow contamination or pollution exist. It has been reported that, at shallow pollution sites, processes such as phytotransformation, rhizosphere bioremediation, phytostabilization, phytoextraction and/or rhizofiltration were best possible to be implemented (Juwarkar, 2012). Industries like textile mills, tanning- leather manufacturing industries, fertilizer factories, mining industries were major sources of contamination where phytoremediation technologies have been promising. To evaluate the potential applications of the plantmicrobe interactions remedial strategies, studies have been performed by researchers (Niti et al., 2013, Sarkar et al., 2010).

\section{Biodegradation and Bioremediation of Chloro/ Nitro/Amino Substituted Aromatic Compounds}

Aromatic compounds namely chlorophenols, p- nitrophenol (PNP), aminophenols, chloronitrophenols and their derivatives are important environmental pollutants because of their toxicity to many living organisms (Arora and Jain 2012, Arora et al., 2014, Kanekar et al., 2014, Sengupta et al., 2015, Kumari et al., 2017).

Both aerobic and anaerobic biodegradation pathways of aromatic compounds and their derivatives have been deciphered by researchers (Arora et al., 2014, Malik et al., 2014, Tiwari et al., 2017, Ghosh et al., 2017); more extensively the aerobic degradation. In bacteria, major pathways reported for catabolism of aromatic compounds have revealed that initial conversion steps were carried out by different enzymes, but the compounds were transformed into a limited number of metabolites, such as protocatechuate and catechols. These intermediate metabolites were channeled into central metabolic routes via; different ring cleavage pathways enzymes. This generalized scheme of catabolic pathways for aromatic compounds suggests that microorganisms have extended their substrate range by developing "peripheral" enzymes, which were able to transform initial substrates into one of the central intermediates like catechol, resorcinol, benzoquinones etc.

Arora et al. 2014 have reported about bacterial degradation of the toxic compound 4-chloro-3nitrophenol (4C3NP) and formation of 4chlororesorcinol intermediate in the degradation pathway. 2-chloro-4-aminophenol degradation by bacteria has also been reported by the same group (Arora et al., 2014, Malik et al., 2014). 4C3NPmineralizing bacterium, Pseudomonas sp. JHN was isolated, by enrichment, from a wastewater sample collected from a chemically-contaminated area in India. Detoxification of 2-chloro-4-nitrophenol (2C4NP) by Cupriavidus strain a3 has been reported by Tiwari et al. 2017. These microbes show potential for application in bioremediation. Microbial Biotechnology Research Laboratory (MBRL) reported a bacterium isolated from limestone deposits in Ukhrul, Manipur, India; two strains, (HS4-2 and HS6-1) were isolated as p-nitrophenol (PNP) degraders via hydroquinone and -nitrocatechol pathways (Ningthoujam et al., 2012). In PNP degradative pathway, 4-nitocatechol and benzenetriol intermediates were mainly formed in Gram negative organism (Chauhan et al., 2010, Qureshi et al., 2002, 
Qureshi et al., 2001). Enzyme p-nitrophenol 4hydroxylase has been reported to be active for parathion biotransformation and further degradation of PNP (Khan et al., 2011, Verma et al., 2011, Wasi et al., 2011, Saha et al., 2014, Goyal and Bansiwal, 2017). Polyphenol oxidase (PPO) enzyme for phenolic contaminants from industrial wastewater has been reported (Mukherjee et al., 2013). Other enzymes such as catechol 1,2-dioxygenase (C12O) and catechol 2.3-dioxygenase $(\mathrm{C} 23 \mathrm{O})$ have been reported to enhance bioremediation process under different conditions (Pandeeti and Siddavattam, 2011, Kumari et al., 2017, Ghosh et al., 2017). Nitroaromatic pollutants trinitrotoluene (TNT) and dinitrotoluene (DNT) degradation has mainly been reported under aerobic conditions (Goel et al., 2012). Also, other pollutants such as 4-nitrobenzoate, 2-nitrobenzoate, 2-nitrotoluene, nitrobenzene, $\mathrm{p}$-nitroaniline and $\mathrm{p}$ nitrophenol were reported to be used as growth substrates by bacteria (Mulla et al., 2011, Srivastava et al., 2013, Qureshi et al., 2001, Qureshi et al., 2002, Mishra and Sardar, 2014, Arora and Sharma, 2015). Under anaerobic condition, nitroaromatic pollutant reduction and biotransformation have been reported by bacteria and their nanobiocomposite as catalyst (Srivastava et al., 2013, Chaudhary et al., 2013).

\section{Biodegradation and Bioremediation of Organo- chlorines and Organophosphates}

Organochlorines viz., DDT- type compounds, cyclodienes like aldrin, dialdrin, endrin, heptachlor, chlordane, endosulphan, lindane, polychlorinated biphenyls etc, organophosphates such as methyl parathion and many chlorinated/nitro/amino-substituted compounds employed as insecticides and pesticides have also been categorized as pollutants. Recently it has been assessed in the Vasai Creek water near Mumbai that organochlorine and organophosphorus pesticide residues were major cause of endocrine disruption leading to ecological risk (Singare, 2016).

Over the past 20 years of organochlorine insecticide lindane production the industry has utilized inappropriate storage and disposal practices, resulting in widespread environmental hexachlorocyclohexane $(\mathrm{HCH})$ contamination and a large number of $\mathrm{HCH}$ dumpsites (Jit et al., 2011). One of the $\mathrm{HCH}$ dumpsites at Ummari village, Lucknow has been studied for characterization of the microbial diversity by culture dependent approach (Singh et al., 2009, Dadhwal et al., 2009, Bala et al., 2010, Sharma et al., 2010, Kumar et al., 2013, Negi et al., 2014, Verma et al., 2014). These studies revealed the presence of potent $\mathrm{HCH}$ degraders and tolerant bacterial species that arose under the $\mathrm{HCH}$ stress. Specifically, many of these bacteria shared components of a unique catabolic system -named the lin system which allowed for the degradation of $\mathrm{HCH}$ isomers (Kumari et al., 2002, Sharma et al., 2006, Lal et al., 2010). These lin genes seem to have played a major role in shaping the degradation of xenobiotic compounds (Dogra et al., 2004) and are diverging to form several catabolic functions (Lal et al., 2006). linA ( $\mathrm{HCH}$ dehydrochlorinase) and linB (halidohydrolase) act as the primary enzymes in the pathway. The linA GC content is lower than that of the linXBCD genes (Suar et al., 2005) linB acts on $\beta-\mathrm{HCH}, \delta-\mathrm{HCH}$ and pentachlorocyclohexanol, yielding a 2,3,4,5,6-pentachlorocyclohexanol (2,3,4,5,6-PCHL), and tetrachlorocyclo hexanediol, respectively (Sharma et al., 2006). LinB protein has a very broad substrate preference for halogenated compounds whereas the substrate range for LinA protein is very restricted to $\alpha-, \gamma-$ and $\delta-\mathrm{HCH}$ and their corresponding $\mathrm{PCCH}$ products (Kumari et al., 2002). It is due to $\mathrm{HCH}$ pressure that LinA proteins are evolving to a greater extent at the dumpsite. LinB, which is evolutionary more advanced and evolved, is evenly distributed at all the contaminated sites (Kumari et al., 2002, Sharma et al., 2006). It has been found that the upper pathway lin genes are constitutively expressed whereas the lower pathway genes are primarily induced in the presence of $\alpha$ - and $\gamma-\mathrm{HCH}$ not $\beta$ - and $\delta$-HCH (Suar et al., 2004). The high residue level is not the only factor: other biological factors like HGT by IS elements and plasmids may be responsible for the high copy number. Bioremediation of $\mathrm{HCH}$ contaminated sites is being attempted by bioaugmentation, biostimulation and enzymatic bioremediation approaches (Lal et al., 2010). Commonly used pesticides namely chloropyrifos have been reported to be utilized by Pseudomonas strain C2A1 as the sole source of carbon and energy (Anwar et al., 2009, Gupta et al.,2016). Degradation of chlorpyrifos have been demonstrated in soil suspension by Das and Adhya 2015. Also reports showed that the capability of microorganism for degradation could be enhanced by characterization and transfer of 
pesticide-degrading genes, induction of catabolic pathways and display of cell surface enzymes (Hussain et al., 2009). Recently researchers are trying to explore Pseudomonas sp to degrade chlorinated pesticides belonging to different chemical categories (Gupta et al., 2016). Endosulphan degradative pathways and the generated metabolites have also been reported (Bajaj et al., 2010).

Many reports are available on organophosphate (OP) pesticides biodegradation by bacteria (Qureshi et al., 2009; Dubey and Fulekar 2012; Sasikala et al., 2012; Iyer et al., 2013; Pinjari et al., 2013; Kundu et al., 2014; Reddy et al., 2016; Chatterjee et al., 2017). Even, several novel bacterial strains have been reported from agricultural field especially located at Narigram in Burdwan district of West Bengal, India. Bacillus aryabhattai, a novel endospore forming strain have been reported to tolerate high concentration (up to $500 \mu \mathrm{g} \mathrm{mL}^{-1}$ ) of pesticide parathion (Pailan et al., 2015). Study on bioremediation of methyl parathion using Pseudomonas sp have also been reported from Visakhapatnam, India (Mulla et al., 2011, Srivastava et al., 2013, Begum and Arundhati, 2016). OP degrading enzymes have been designated as Phosphotriesterases (PTEs) as they are involved in hydrolysis of triester linkage found in OP compounds. The PTEs are classified into three major groups, i.e. organophosphate hydrolases $(\mathrm{OPH})$, methyl parathion hydrolases (MPH) and organophosphate acid anhydrases (OPAA). The OPAA is later shown to be dipeptidase and its activity on OP compounds is shown due to structural similarities between OP compounds and dipeptides having proline at the $\mathrm{C}$ terminus. However, the physiological substrates for $\mathrm{OPH}$ and MPH are unknown. Considering the catalytic efficiency and structural similarities with the structure of quorum quenching lactonases, the $\mathrm{OPH}$, the product of organophosphate degrading (opd) gene, is assumed to have evolved from phophotriesterase like lactonases (PTLL). The genetic organization of opd gene in both Flavobacterium sp. and in Pseudomonas diminuta have been elucidated. These two strains have been reclassified and renamed as Sphingobium fuliginis ATCC 27551 and Sphingophyxis wildii (Parthasarathy et al., 2016a). In these two soil isolates the opd gene is found in large indigenous plasmids. The $65 \mathrm{~kb}$ plasmid pCMS1, isolated from Sphingopyxis wildii has been shown to be a self-transmissible plasmid and is involved in spreading opd information among soil microflora (Pandeeti et al., 2011). Similarly, the plasmid pPLD2 is shown to be an Integrated Mobilizable Element (IME) (Pandeeti et al., 2013). In plasmid pPDL2, the opd along with an ORF, orf306 is flanked by mobile genetic elements (Pandeeti et al., 2013). The Orf306 is an esterase. When it is expressed it E. coli, the cells have started degrading p-nitrophenol, the recalcitrant degradation product generated during OPH mediated hydrolysis of OP insecticides. Transcriptome analysis for the $E$. coli strains grown in presence and absence of Orf306. The Orf306, in an unknown way, is shown to down regulated glycolysis and TCA cycle and upregulated both hca and $m h p$ operons involved in degradation of phenylpropionate and hydroxylphenyl propionate. The enzymes encoded by hca and mhp operons are shown to degrade p-nitrophenol (Chakka et al., 2015). The IME borne opd product (OPH) along with Orf306 is shown to contribute for mineralization of insecticide residues found in soil by stimulating the innate nitrophenol degrading ability of recipient strains. The work done has also shown OPH association with membrane associated transport system involved in phosphate transport. The genetic and biochemical evidences suggest that $\mathrm{OPH}$ is involved in phosphate acquisition in soil bacteria (Parthasarathy et al., 2016b).

\section{Biodegradation and Bioremediation of Hydrocarbons and Crude Oil}

Crude oil and hydrocarbons comprises of saturates/ paraffins, aromatics, resins and asphaltenes. Scientific communities are being urged to develop strategies to minimize the concentrations polyaromatic hydrocarbons (PAHs) from the Gujrat coastlines and restore sites by investigations (Dudhagara et al., 2016). Reports are available consistently on metabolic diversity and versatility of pure cultures and mixed cultures respectively to utilize hydrocarbon pollutants in petroleum crude as carbon source (Varjani and Upasani, 2016). It has been reported that even coculture(s) of bacteria and fungi enhance degradation rates of diesel oil and PAHs under laboratory conditions (Varjani and Upasani, 2013).

Bioremediation technologies have been reported to be applied to restore petroleum hydrocarbon polluted environments that makes use of natural microbial 
biodegradation activity (Varjani, 2017). Both in-situ and on-site treatment process have been reported to breakdown crude petroleum oil components at contaminated sites. In 2007, Das and Mukherjee have studied and compared the efficiency of thermophilic Bacillus subtilis DM04 strain and Pseudomonas aeruginosa $\mathrm{M}$ bacteria isolated from North East India for biodegradation of crude petroleum oil.

Bacillus spp. and Pseudomonas have been found suitable for practical field applications for effective PAH and aromatic compounds bioremediation at contaminated sites (Khanna et al., 2011, Sood et al., 2010, Phale et al., 2013, Phale et al., 2007). Even high-altitude bacteria have been reported to be capable of degrading engine oil (Jain et al., 2010). Recently, B. licheniformis CFR1 is reported as an excellent candidate for bioremediation and detoxification of aflatoxin (Rao et al., 2017). Novel, thermally stable, halotolerant enzymes like cellulases have been reported to perform in harsh conditions such as high salt, heat and acidic environments (Chandel et al., 2007, Garg et al., 2016).

Bacterial community found in an Indian coal bed has been reported to be capable of in-situ biotransformation of coal into methane (Singh et al., 2012, Singh and Tripathi 2013, Mohanty et al., 2016). Such findings would assist in bioremediation of such contaminated ecosystems.

Recently it has been reported that oleophilic microorganisms could be used for oil spill bioremediation (Varjani, 2017). Scientific communities are being urged to develop strategies to minimize the concentrations of pollutants for examples PAHs from the Gujrat coastlines and restore sites by investigations (Dudhagara et al., 2016). In the similar lines, there is a big break through achieved, in the area of remediation of crude oil contaminated sites, where the technology "Oilzapper" has been successfully demonstrated at commercial scale at various site and received global acceptance (Sharma et al., 2019).

\section{Biodegradation and Bioremediation of Metals and Heavy Metals}

Toxicity of metals to ecosystems and their mobility in biological systems needs to be highlighted in Indian scenario. In 2014 Mani and Kumar have reviewed the bioremediation options especially using microorganisms and plants with eco-friendly and sustainable approach in Indian context. Reports have been available for metal binding proteins or peptides for their potential towards tolerance and accumulation in living systems especially with cadmium which is found significantly in foods (Mejare and Bulow, 2001). Molecular level studies of metal tolerance genes in microorganisms and hyper accumulator plants showed involvement of functional genes for detoxification (Dixit et al., 2015). Also, bioabsorbent such as fungi viz; Phanerochaete chrysosporium, Aspegillus awamori, Aspergillus flavus, Trichoderma viride are reported for removal of heavy metals from industrial effluent by Joshi et al., 2011. Fungi such as Tirchoderma with plant growth promoting (PGP) abilities have been reported as efficient biocatalyst and potent antimicrobial agents (Mishra et al., 2014, Monaharachary et al., 2014, Singh et al., 2014). Removal of metal(loids) using organic amendments such as compost, MSW as nutrients and soil conditioners have been discussed with practical implications to bioavailability by Park et al., 2011. Role of EPS from various sources with special emphasis on bioremediation of heavy metals have been studied by researchers (Pal and Paul 2008, Ahemad 2012). The applicability of chromium resistant fungal species viz., Micrococcus sp and Aspergillus sp for removal of chromium and nickel up to $10,0000 \mathrm{mg} / \mathrm{L}$ have been reported (Congeevaram et al., 2007). The potential of bacterial genera (Pseudomonas, Entetobacter, Bacillus, E.coli), yeast and fungal species for bioremediation of metal toxicity have been discussed and their impact on environment is also illustrated by Ray and Ray 2009. The mechanism of removal of metal by biological means have been reported where it was found that Pi precipitates the heavy metals as phosphate-metal complexes (Chaudhari et al., 2017). Bioremediation of electroplating industrial wastewater with simultaneous nanoparticles synthesis also have been reported (Sathyavathi et al., 2014, Dasgupta et al., 2015). Several biological methods of heavy metal remediation have been reported by both bacteria and fungi (Kundu and Gupta 2007, Singh and Prasad 2015, Chaudhary et al., 2017, Nagvenkar and Ramaiah 2010).

\section{Treatment of Textiles Dyes}

Ichalkaranji and nearby places in Maharashtra are 
well known as the textile hub of the state. A large number of large, small and even household dye processors are located in this part. Because of the uncontrolled discharge of the toxic textile dye-stuff in environmental sink, water bodies and soils in the said area have become heavily polluted. The Department of Biochemistry, Shivaji University research group lead by Prof. S. P. Govindwar has been actively involved to find out novel and developed ecofriendly bioremediation strategies for the treatment of these noxious dyes.

In the last five years, a number of bacteria such as Lysinibacillus sp. RGS, Providencia rettgeristrain HSL1, Pseudomonas sp. SUK1, Bacillus thuringiensis, Pseudomonas sp. LBC1, Pseudomonas monteilii ANK, Pseudomonas putida $\mathrm{PgH}$, Brevibacillus laterosporus, Bacillus cereus EBT1 and Kocuria rosea MTCC 1532 etc. have been explored for the treatment of textile dyes. Fungal species namely, Galactomyces geotrichum MTCC 1360 and Aspergillus ochraceus NCIM-1146 were also utilized for detoxification of dyes (Saratale et al., 2011). Novel lichen species called Permeliaper lata was also found to treat the textile dyes to significant extents (Kulkarni et al., 2014). Combinatorial systems of bacteria and fungi such as Galactomyces geotrichum MTCC 1360-Brevibacillus laterosporus MTCC 2298 and Aspergillus ochraceus NCIM1146-Pseudomonas sp. SUK1 was observed to be more efficient than the individual cultures in treatment and decolorization of dyes. Of late, plant and bacterial hybrid systems of Zinnia angustifolia-Exiguobacterium aestaurii, Portulaca grandifloraPseudomonas putida and Pogonatherum crinitumBacillus pumilus were also explored in the constructed wetlands systems for efficient removal of textile dyes from real effluents (, Khandare and Govindwar, 2015). A novel bioreactor with Ipomoea hederifolia adventitious roots and its endophyte Cladosporium cladosporioides was developed for textile dye degradation (Patil et al., 2016). A variety of bioreactors using bacteria were also developed for the treatment of dyes from effluents. The decolorization of real textile industry effluent using immobilized bacterial yeast consortium of Galactomyces geotrichum MTCC-Brevibacillus laterosporus MTCC in a newly developed triple layered fixed bed bioreactor and the efficiency and performance was tested in continuous operation
(Kurade et al., 2017). Degradation and detoxification of methylene blue dye adsorbed on water hyacinth in semi continuous anaerobic-aerobic bioreactors was also carried out in a novel microbial consortium of Sacharromyces cerevisiae and Bacillus sp. STIS (Bedekar et al., 2015). Solid state fermentation of the bioadsorbed textile dyes stuffs and distillery industry waste-yeast biomass has been successfully carried out using Bacillus cereus EBT1 (4, Kadam et al., 2013). In independent studies, influence of diazo dyes on soil bacterial population was monitored. Molecular analysis of shift in community after different time intervals was monitored by using PCR-DGGE targeting V3 region of bacterial 16S rRNA gene. UV irradiation was used to introduce random mutations in Pseudomonas sp. LBC1. Genetic alterations induced by UV irradiation in selected mutant bacteria were confirmed by random amplification of polymorphic DNA technique. The mutant bacteria named as Pseudomonas sp. The dye treatment efficiency of the mutant was found to be improved after mutagenesis (Joshi et al., 2013). Different oxidoreductive microbial enzymes like lignin peroxidase, manganese peroxidase, aryl alcohol oxidase, laccases, tyrosinase, azo reductase, malachite green reductase, DCIP reductase and riboflavin reductase attacks the complex dyes structure and metabolize them through steps like deamination, desulfonation, dehalogenation, hydroxylation, oxidation, reduction, ring opening and cleavage mechanisms. The direct roles of these enzymes have been proved using standard purification protocols (Telke et al., 2015). The metabolites of dye degradation were analyzed by using UV-Visible and FTI-R spectroscopy, HPLC, HPTLC, GC and/or LCMS and NMR techniques. Textile effluents generally have very high COD, BOD, TOC, TDS, TSS, alkalinity, conductivity etc., therefore the microbes which can only survive these stressful conditions could only show dye removal efficacies. The toxicity assessment of dyes, effluents and their metabolites after bioremediation have been carried out using plant, microbes and animal models looking for cytotoxicity and genotoxicity. An intensive research on utilization of bacteria at the large industrial scales is underway and an efficient reactor set up is still awaited.

Effluents generated from the textile mills are one of the major sources of point pollution in rivers. In view of the requirement of color free discharge and detoxified waters, several lines of treatment have 
been tested. These include conventional physical as well as advanced biological oxidation processes such as treatment with $\mathrm{TiO}_{2}, \mathrm{UV}$, Fenton and photo-Fenton oxidations. Many of these do not work effectively on complex azo and pthalocyanine dyes. Laccases and several other oxidoreductases have been identified as promising candidates for decolouration as well as detoxification. The group of Prof. Saroj Mishra uses laccase from Cyathusbulleri (Salony et al., 2006) effectively for decolouration of several category of dyes. The reaction centre of this enzyme is made from closely spaced $\mathrm{Cu}$ atoms arranged in the form of three reaction centres, namely $\mathrm{T} 1, \mathrm{~T} 2$ and $\mathrm{T} 3$. Out of these, the geometry at the $\mathrm{T} 1 \mathrm{Cu}$ centre determines the redox potential of the enzyme and its ability to oxidize dyes of high redox potential (Salony et al., 2008). The property of laccase to act on complex dyes as well as real effluent can be further augmented by addition of small mediators in the reaction mixture, protein engineering, supplementation with other powerful oxidoreductase enzymes such as cellobiose dehydrogenases or by producing laccase on complex lignocellulosics such as wheat bran. These approaches have been successfully used in the lab. Amongst a number of mediators, 2,2'-azino-bis (3-ethylbenzothiazoline-6-sulphonic acid) or ABTS and natural mediator vanillin were found to be very effective (Chhabra et al., 2008) against a wide range of dyes as well as combined effluent collected from textile mills. Based on these findings, a continuous membrane reactor was designed and successfully operated for decolouration of real effluent (Chhabra et al., 2009) using laccase and a synthetic mediator. The treatment with laccase was extended to complex effluents by combining a chemical step (alum treatment) during the early processing stage (Chhabra et al., 2015a). Operationally, the system was equally effective in handling a variety of Reactive dyes (Chhabra et al., 2015b). In the second approach, random mutagenesis was carried out of the C-terminal half of the coding gene (Garg et al., 2012; Kenzom et al., 2014) and mutant library (Kenzom et al., 2015) screened for catalytically superior enzymes. Many of these were effective on pthalocyanine dyes as well. Through biochemical and model building, amino acid residues were identified that affect catalytic activity. (In another approach, combination of laccase with cellobiose dehydrogenase was found to be highly active on pthalocyanine dyes (Bashir et al., 2015;
Gangwar et al., 2016) with extensive degradation noticed of this category of dyes. The treatment on real effluent indicated this combination of enzymes (wild type and the mutant ones) to be effective for both decolouration and reduction in phytotoxicity. Several other mutants available in the author's laboratory are being analysed to identify sites in the enzyme that determine the redox potential as well as the electron transfer property of laccase. The efficacy of laccases produced on complex lignocellulosics was recently demonstrated on complex effluent from denim dying industry (Vats and Mishra, 2017) indicating these to be promising in treatment of textile wastewaters.

\section{Bioremediation of Soil Salinity}

Papers published in Nature in 1950s claimed saline soil reclamation using native populations of cyanobacteria, based on which ICAR advocated use of these microbes for such purpose. Dr. Apte's laboratory demonstrated that actually sodium exclusion and its entrapment in extracellular polysaccharides underlie cyanobacterial tolerance to salinity (Apte and Thomas, 1986). While this provides temporary relief to a growing crop by transient sequestration of sodium/chloride ions and by supplementing fixed nitrogen, the technology offers no permanent solution to the problem of soil salinity which is restored subsequent to death and decay of cyanobacteria (Apte and Thomas, 1997). The work also revealed entirely different mechanisms to be involved in salinity and desiccation tolerance (Apte, 2001). Agronomic practices which curtailed sodium influx enhanced salt tolerance (Apte et al., 1987). Desiccation tolerance, in contrast, depended on de novo synthesis of osmotic stress proteins (Fernandes et al., 2000).

\section{Integrating Conventional Bioremediation Technology with Genomics}

Over the years it has been learnt that for successful implementation of biological remediation technologies, multidisciplinary approach from experts of various areas are required. Moreover, for effective bioremediation, complete understandings of environment (i.e. physical, chemical and biological properties) to be treated are essential. With the advancement in the technology, our lab has integrated the conventional approach with genomics-driven strategies to make bioremediation technologies more 
potent. We perused the hypothesis that microbes are the best answer for counteracting the devastating consequences of our activities on environment. And to demonstrate the viability of our proposition, we have developed and enriched more than 100 bacterial consortia (mixed cultures) and isolated bacterial pure cultures from polluted soil, sediments, water, industrial and CETP effluents exhibiting significant degradation potential for various dyes and dye intermediates, aromatics, polyaromatic hydrocarbons $(\mathrm{PAH})$, distillery spent wash and detoxification of heavy metals under different environmental conditions (anaerobic, microaerophilic, aerobic, sequential microaerophilicaerobic and anaerobic-microaerophilic) (Patel et al., 2012a and b; Jain et al., 2012; Shah and Madamwar, 2013a; Patel and Madamwar, 2013; Balapure et al., 2014; Chattaraj et al., 2016a; Shah et al., 2016a). The flask scale results were reevaluated during scaling up process in various bioreactors (anaerobic biphasic fixed film, sequential anoxic-oxic batch process, sequential anaerobic-microaerophilic process, periodic discontinuous batch operation) and processes were optimized for simulated and real industrial effluents (Acharya et al., 2011; Shah et al., 2016b; Chattaraj et al., 2016b; Venkata et al., 2012; Balapure et al., 2016). It is imperative to know the degradation mechanism of the xenobiotic compounds to make technology more robust. Our studies show that due to consorted metabolic activities of the consortia complex aromatic compounds such as dyes, PAH are gradually degraded into simpler intermediates through generating different intermediates and finally led to the complete mineralization via TCA cycle. With two different consortia the degradation pathways for degradation of reactive azo dye Remazol Brilliant Violet 5R (i.e. Reactive Violet 5R) was proposed and observed that the dye was metabolized through formation of â-naphthol and benzene sulphoate (Jain et al., 2012; Shah et al., 2016a). In PAH degradation (phenanthrene), the study revealed that the compound was degraded through phthalic acid-protocatechuate acid pathway (Patel and Madamwar, 2013). During azo dye degradation the initial step is the reduction of azo bonds $(-\mathrm{N}=\mathrm{N}-)$, catalyzed by azoreductase. One of such azoreductases was cloned from consortia V9 of $537 \mathrm{bp}$ containing an ORF of 178 amino acids showing optimum activity in the presence of NADPH. The host harboring azoreductase clone showed $90 \%$ azoreduction within $7 \mathrm{~min}$ in cell free extracts (Shah and Madamwar, 2013a). On the course of developing feasible bioremediation strategy, whole genome of three bacterial cultures, Paenibacillus sp. strain DMB20, Achromobacter sp. strain DMS1 and Paenibacillus sp. strain DMB5 (showing <97\% similarity of phylogenetic marker with available database) was sequenced. Annotation of these genomes revealed the presence of various genes required for aromatic degradation, antibiotic and heavy metal resistance, towards stress response in all three strains, which signifies their active role in xenobiosis (Shah et al., 2015; Amin et al., 2015; Johnson et al., 2016). The complete degradation pathway for benzonitrile, benzamide, benzoate, and catechol degradation was mapped in Paenibacillus sp. strain DMB5 (Johnson et al., 2016). Besides whole genome, we have sequenced more than 10 metagenomes from different polluted sites across the 'Golden Industrial Corridor' of Gujarat State, corresponding to about 8 Gb base pairs. Nearly 100,000 reads corresponding to $>300$ enzymes and enzymatic pathways potentially involved in biodegradation of xenobiotic compounds were mapped. Complete and partial degradation pathways for several xenobiotic compounds were mapped (Shah et al., 2103b). The diversity community shift due to persistent pollution at certain polluted sites was also evidently observed (Patel et al., 2014, 2015). The work describes the potential of bacterial system to utilize the recalcitrant xenobiotics and community organization at polluted environment along with their functional capabilities by knowing their genetic composition. Nonetheless, it is a preliminary study for complete understanding of entire ecology/ ecosystem of polluted environment to improve the natural bioremediation.

\section{Consortium Development in Bioremediation}

Remediation of contaminated resources is one of the major thrust areas of the National Environmental Engineering Research Institute (NEERI). Since, bioprocesses play key role in remediation, especially when the contamination is of organic nature, major thrust was taken in the area of optimization of such processes (Purohit et al., 2003a, Purohit et al., 2003b, Moharikar et al., 2005, Kapley and Purohit, 2009). Bioremediation processes are employed either for biostimulation or for bio-augmentation (Khardenavis et al., 2008, Khardenavis et al., 2010, Paliwal et al., 2012, Purohit et al., 2016). The strategy involved in 
this program is to enrich and select bacteria, which have the potential to utilize target pollutants as carbon source for their growth. The selected pollutants were hydrocarbon, -nitro and -chloro substituted pesticides and intermediates used for synthesis of pesticides and pharma products. The studies over a period of 10 years a bank of isolates was established from different environment with wide catabolic potential (Selvakumaran et al., 2008; Thangraj et al., 2008, Verma et al., 2011). Since, most of these contaminated sites show a multi-substrate challenge, the defined mixtures of bacteria with selected genotype were used to design consortia with flexible degradative capacities (Selvakumaran et al., 2011).

The pollutant targeted in the program included the hydrocarbons from crude oil (aromatics and long chain aliphatic), nitro and -chloro substituted aromatics or heterocyclics. Enrichment techniques were designed to isolate for these difficult to degrade molecules. One of the major achievements was the development of a consortium of four bacteria, which could emulsify and degrade the crude oil efficiently in $12 \mathrm{~h}$. These cultures were used for development of wastewater treatment process (Moharikar et al., 2005, Kapley et al., 2007, Domde et al., 2007). Another area of application was the remediation of contaminated soil. Initially controlled microcosm experiments were planned using designed bacterial consortia, which were further evaluated using pilot scale field trials; and demonstrated to user agencies (Qureshi et al., 2009). Different bioremediation processes were designed either by using biostimulation (balancing of nutrients or induction of degradative capacities using inducer molecules) or by bio-augmentation (applying the required bacteria to bring out the degradation). These studies were supported by characterization of the associated genotypes that were predicted by annotation of genome sequence data and revealed the basic mechanism of degradation pathways for hydrocarbons, p-nitrophenol and atrazine (Tikharia et al., 2016).

The biostimulation to enhance the expression of degradative capacities was carried out using the intermediate of the metabolism such as catechol, salicylate and even phenol and analyzed for different aromatic ring cleavage enzymes (Selvakaumaran et al., 2011). Similarly, the metal ions were also used while the sludge was recycled for enhancing the required catabolic potential to microbial community. The other issues is for difficult to degrade wastewaters such as dye containing waste for that consortiums has been prepared (Dafale et al., 2010) and also to solve the issue of generated increase in ammonia level has been dealt with specialized organisms (Khardenavis et al., 2007; Pal et al., 2015).

\section{Engineering Microbes Towards Bioremediation}

Biodegradative potential of degraders can overlap with bacteria from unrelated genera, or alternatively, genes with completely different sequences can catalyze the same reaction. Understanding these complex reactions requires a multi-dimensional approach of whole genome sequencing and bioinformatics analysis of sequence data (Sagarkar et al., 2016). Next generation sequencing technologies allows us to explore the complete catabolic profile of the isolate and this tool has been used to identify many multi-substrate degrading bacteria used in soil microcosm/mesocosm studies. Taking this further into in situ bioremediation of contaminated soil is more complex. Environmental scenarios very often involve more than one contaminant and the microbial community containing different metabolic pathways is governed by diverse soil types and characteristics, climate conditions and anthropogenic activities. These shortcomings are now being addressed via the systems biology approach that analyzes interactions between microbes and their environment and helps predict their function and survival (Chakraborty et al., 2012).

Mapping the microbial populations of a contaminated niche allows for a systematic development of a bioremediation strategy. The metagenomics tool provides insight into the phylogenetic composition of the microbial community as well as its functional genes (Jadega et al., 2014; Yadav et al., 2014). Shifts in microbial community of a wastewater treatment plant have been demonstrated to correlate with performance efficiency (Kapley et al., 2015). Besides analyzing the community function, the new tools generate information on the structure and function of catabolic enzymes, the actual unit carrying out the biodegradation process. Knowledge of their detailed structure offers options for improvement by site directed mutagenesis or cloning 
that can improve the efficiency of the reaction or provide the degradative capacity where it did not exist (Bassalo et al., 2016). More recently, researchers have engineered metabolic pathways in microorganisms to generate engineered biocatalysts. Despite the evolution of tools and increased knowledge database, the field application of bioremediation progresses slowly and more studies need to be directed towards the survival and performance efficiency of target microbes in field conditions.

\section{Engineering Cyanobacteria for Enhanced Nitrogen Biofertilizer Potential in Stressful Agricultural Environments}

Discoveries in Dr. Apte's laboratory that stressresponsive gene expression in cyanobacteria has a generic stress response and a stress-specific response (Apte and Bhagwat, 1989; Bhagwat and Apte, 1989; Alahari et al., 2001; Alahari and Apte, 2004), led to discoveries of genes important for survival under major agricultural stresses, such as salinity and heat-shock (Rajaram and Apte, 2003 and 2010; Rajaram et al., 2014), both of which diminish nitrogen fixation. Several of these genes were cloned using the versatile approach of differential RNA hybridization developed by him (Apte and Haselkorn, 1990) or by cloning of stress-specific genes (Rajaram et al., 2001). Mutagenesis and/or overexpression of these genes established their distinct role in general/specific stress tolerance (Chaurasia and Apte, 2009; Rajaram and Apte, 2008). The genes were engineered in to nitrogen-fixing Anabaena strains and expressed from strong light-inducible $p s b A 1$ promoter to further enhance the inherent stress tolerance of these strains. An eco-friendly, integrative expression vector was developed for Anabaena for the first time and used to construct recombinant strains with enhanced nitrogen biofertilizer potential in stressful environments (Chaurasia and Apte, 2011).

\section{Engineering Cyanobacteria For Oxidative Stress Tolerance}

Realization from Dr. Apte's work that oxidative stress is central to all the abiotic stresses, led to the identification of oxidative stress responsive genes and proteins using genomic, transcriptomic and proteomic approaches, in three Anabaena strains typical of Indian paddy fields (Panda et al., 2014 and 2015).
Biology of several oxidative stress alleviators, such as MnSOD, FeSOD, Mn-Catalases, and 4 peroxiredoxins unique to cyanobacteria was elucidated from his laboratory (Raghavan et al., 2011, 2013 and 2015; Bannerjee et al., 2012a and 2012b). All the corresponding genes and their variants were also overexpressed in Anabaena to demonstrate enhanced oxidative stress tolerance as also tolerance to other environmental stresses (Bannerjee et al., 2013).

\section{Engineering Deinococcus radiodurans for Enhanced Oxidative Stress Tolerance and Uranium Bioremediation}

Dr. Apte's laboratory also took the lead in unravelling the molecular basis of extreme radioresistance in Deinococcus radiodurans and contribution of its DNA repair and oxidative stress tolerance abilities to this phenomenon in particular (Misra et al., 2004 and 2006). A novel molecule pyrroloquinoline quinone (PQQ) was characterized from this microbe and shown to play very important role in radioprotection in vitro and in vivo in D. radiodurans (Misra et al., 2004). Transgenosis of PQQ synthase gene was also shown to enhance oxidative stress tolerance of $E$. coli significantly (Khairnar et al., 2003). PQQ was also shown to play a role in radiation-induced signalling and induction of DNA repair through a periplasmic protein kinase (Khairnar et al., 2007). D. radiodurans was found to survive very high oxidative stress triggered by exposure to tellurite. Using genomic and proteomic approaches its tolerance to radiation was shown to be superior to tellurite induced oxidative stress, though the two stress responses shared a lot of common genes and proteins (Narasimha et al., 2015).

On account of its radioresistance, $D$. radiodurans is an automatic choice for bioremediation of nuclear waste. Acid and alkaline phosphatase genes ( $p h o N$ and $p h o K$, respectively) were engineered into this microbe to construct strains that could bioprecipitate uranium from low concentrations of $0.5 \mathrm{mM}$ up to $10 \mathrm{mM}$ over a $\mathrm{pH}$ range of 5-9, resulting in impressive uranium loading of up to $7-10 \mathrm{mg} / \mathrm{g}$ dry biomass (Appukuttan et al., 2006; Nilgiriwala et al., 2008 and 2009; Kulkarni et al., 2013). The phosphatase activity and uranium bioprecipitation capabilities were retained up to 2 years in lyophiliozed cells (Seetharam et al., 2009; 
Appukuttan et al., 2011). At acidic $\mathrm{pH}$ precipitated $\mathrm{U}$ was cell bound and easy to recover by settling and decantation, while at alkaline $\mathrm{pH}$ the extracellular precipitate could be immobilized in to columns and beads for online Uranium remediation in a flow through system and facilitated complete and easy recovery of U (Seetharm-Misra et al., 2012; Kulkarni et al., 2013 and 2016). Methods were also developed for surface display of bioremediation-active proteins in $D$. radiodurans by tagging them to surface layer proteins (Seetharam-Misra et al., 2014). Radiation responsive promoters have been characterized from this microbe (Ujaoney et al., 2010; Narasimha et al., 2016 and 2017) and used to express phosphatases to further enhance $U$ bioremediation in high radiation environments (Seetharam-Misra et al., 2014). The bacterium has also been engineered to express plant $\mathrm{NiCoT}$ genes for purpose of removal of cobalt from waste solutions (Gogada et al., 2015).

\section{Developing Cyanobacteria for Uranium Bioremediation}

Uranium resources on land are getting depleted with time and a novel idea is to recover uranium from extremely low concentrations of $3 \mathrm{ppb}$ from the seawater which holds nearly $60 \%$ of Earth's uranium. Marine cyanobacteria (Synechcoccus elongatus and Anabaena torulosa) were developed to sequester $\mathrm{U}$ from such low concentration and at an alkaline $\mathrm{pH}$ of 7.8, typical of seawater (Acharya et al., 2009 and 2012a). The sequestered U was shown to be immobilized in extracellular polysaccharides or in unique surface associated polyphoshate bodies in marine cyanobacteria (Acharya and Apte, 2013a and 2013b). Proteomic analyses revealed that the ability to prevent availability of $U$ in the cytosol underlies uranium tolerance of certain Anabaena species (Panda et al., 2017). Such strains have also been used to remove $\mathrm{U}$ from $\mathrm{RO}$ water generated from desalination plants (Acharya et al., 2012b).

\section{Developing Microbes for Biodegradation of Organic Solvents and Pesticides}

Dr. Apte's laboratory was the first in India to demonstrate the molecular basis of lindane (ã-HCH or ã-hexachlorocyclohexane) biodegradation from Sphingomonas paucimobilis (Adhya et al., 1996) that subsequently led to cloning of several of the corresponding $\operatorname{lin} A$ and $\operatorname{lin} B$ genes and their variants from several Sphingomonas spp. in India. His laboratory also overexpressed the $\operatorname{lin} A$ gene in (a) $E$. coli to construct a very sensitive and robust biosensor for lindane (Anu-Pratap et al., 2012), and (b) Anabaena to develop a lindane biodegrading strain for rice field (Chaurasia et al., 2013). They also isolated and characterized Sphingobium sp. strain RSMS, capable of degrading tributyl phosphate (TBP) and utilizing it as carbon and phosphorus source resulting in complete mineralization of this recalcitrant organic solvent of $\mathrm{U}$ and $\mathrm{Pu}$ in nuclear industry (Rangu et al., 2014). The biochemical pathway of TBP degradation was elucidated and techniques developed to simultaneously degrade TBP and use the phosphate released for precipitation of traces of uranium still present in TBP (Rangu et al., 2016).

\section{Pseudomonas spp: Degrader of Many Aromatics}

Pseudomonas putida CSV86: An evader of CCR. P. putida CSV86, a soil isolate from Dr. P Phale lab, utilizes an array of aromatics as the sole source of carbon and energy. This strain has a unique ability to utilize aromatics preferentially over glucose and cometabolizes aromatics and organic acids (Basu et al., 2006). Aromatics and organic acid mediated repression of glucose metabolism as well as transport was found to be responsible for this ability. In the strain CSV86, glucose to enters only through high affinity ATP dependent $\mathrm{ABC}$ transporter. This transport system comprises of a periplasmic glucose binding protein, GBP; outer membrane porin, OprB; two inner membrane $\mathrm{ABC}$ transporter proteins, GlcF and GlcG and a membrane bound cytoplasmic ATPase, GlcK (Figure 6C) and present together as a probable transcription unit (Paliwal et al., 2014). The periplasmic glucose binding protein confers specificity to this system and has been studied at the structural level to understand the basis of the specificity (Figure 6D, Modak et al., 2014, Pandey et al., 2016).

Pseudomonas aeruginosa strain PP4. Phthalate degradation: P. aeruginosa strain PP4 is a soil isolate, capable of degrading phthalate isomers (phthalate, isophthalate and terephthalate) as sole sources of carbon and energy. Studies revealed that strain PP4 utilize phthalates efficiently by overcoming the metabolic inhibition adapting different strategies like modulating different forms of GDH or expressing higher concentration of the same enzyme (Vamsee- 
Krishna and Phale, 2010), suggesting it to be a better candidate for the on-site bioremediation.

Pseudomonas sp. strain C5pp: Evolution in process: Carbaryl (1-naphthyl $N$-methylcarbamate) is widely used as a broad-spectrum insecticide. Pseudomonas sp. strain C5pp isolated from soil metabolizes carbaryl as the sole source of carbon and energy. Carbaryl is metabolized via 1-naphthol,1,2dihydroxynaphthalene, salicylaldehyde, salicylate and gentisate to TCA cycle intermediates. The carbonsource dependent enzyme induction studies suggested that carbaryl degradation pathway is segmented into 'upper', 'middle' and 'lower' (Singh et al., 2013) pathway. The combined approach of genomic library analysis and genome sequencing was used to identify

\section{References}

Acharya BK, Pathak H, Mohana S, Shouche Y, Singh V and Madamwar D (2011) Kinetic modeling and microbial community assessment of anaerobic biphasic fixed film bioreactor treating distillery spent wash Water Res 45 42484259

Acharya C and Apte SK (2013a) Insights into the interactions of cyanobacteria with uranium Photosynth Res 118 83-94

Acharya C and Apte SK (2013b) Novel surface associated polyphosphate bodies sequester uranium in the filamentous, marine cyanobacterium Anabaena torulosa Metallomics 5 1595-1598

Acharya C, Chandwadkar P and Apte SK (2012a) Interaction of uranium with a filamentous, heterocystous, nitrogen-fixing cyanobacterium, Anabaena torulosa Biores Technol 116 290-294

Acharya C, Chandwadkar P, Joseph D and Apte SK (2012b) Uranium (VI) recovery from saline environment by a marine unicellular cyanobacterium, Synechococcus elongates $J$ Radioanal Nucl Chem 295 845-850

Acharya C, Joseph D and Apte SK (2009) Uranium sequestration by a marine cyanobacterium Synechococcus elongatus BDU/75042 Biores Technol 100 2176-2181

Adhya TK, Apte S, Raghu K, Sethunathan N and Murthy NBK (1996) Novel polypeptides induced by the insecticide lindane (?-hexachlorocyclohexane) are required for its biodegradation by a Sphingomonas paucimobilis strain Biochem Biophys Res Commun 221 755-761

Ahemad M (2012) Implications of bacterial resistance against heavy metals in bioremediation: a review Journal of Institute the genes involved in carbaryl metabolic pathway. The sequence analysis suggested genes involved in the pathway have been acquired as a result of horizontal gene transfer.

Strain C5pp appears to be in early stages of evolution and can serve as an interesting model for studying evolution of metabolic pathway for recently introduced pesticide. As strain CSV86 has ability to preferentially utilize aromatics (globally) over simple carbon source like glucose it increases the potential for its use in biodegradation and biorefinery. Moreover, this strain also serves as efficient genetic tool for studying and metabolic engineering, so as to construct a robust strain for efficient removal of aromatic pollutants from the contaminated environment.

of Integrative Omics and Applied Biotechnology 3

Alahari A and Apte SK (2004) A novel potassium deficiencyinduced stimulon in Anabaena torulosa" J Biosci 29 153161

Alahari A, Ballal A and Apte SK (2001) Regulation of potassiumdependent Kdp-ATPase expression in the nitrogen-fixing cyanobacterium Anabaena torulosa J Bacteriol 183 57785781

Amin S, Shah B, Jain K, Patel A, Patel N, Joshi CG and Madamwar D (2015) Draft genome sequence of Achromobacter sp strain DMS1, capable of degrading polyaromatic hydrocarbons isolated from the industrially perturbed environment of Amlakhadi canal, India Genome Announc 3 e01264-15

Anu Prathap MU, Chaurasia A, Sawant S and Apte SK (2012) Polyaniline based highly sensitive microbial biosensor for selective and rapid detection of lindane" Anal Chem (dxdoiorg/101021/ac301077d)

Anwar S, Liaquat F, Khan QM, Khalid ZM and Iqbal S (2009) Biodegradation of chlorpyrifos and its hydrolysis product 3, 5, 6-trichloro-2-pyridinol by Bacillus pumilus strain C2A1 Journal of Hazardous Materials 168 400-405

Appukuttan D, Rao AS and Apte SK (2006) Engineering Deinococcus radiodurans $\mathrm{R} 1$ for bioprecipitation of uranium from dilute nuclear waste Appl Env Microbiol 72 7873-7878

Appukuttan D, Seetharam C, Padma N, Rao AS and Apte SK (2011) PhoN expressing, lyophilized, recombinant Deinococcus radiodurans cells for uranium bioprecipitation J Biotechnol 154 285-290 
Apte SK (2001) Coping with water stress: cyanobacteria show the way Proc Indian Natn Sci Acad (PINSA) B67 285-310

Apte SK and Bhagwat AA (1989) Salinity stress induced proteins in two nitrogen-fixing Anabaena strains differentially tolerant to salt $J$ Bacteriol 171 909-915

Apte SK and Thomas J (1986) Membrane electrogenesis and sodium transport in filamentous nitrogen-fixing cyanobacteria Eur J Biochem 154 395-401

Apte SK and Thomas J (1997) Possible amelioration of coastal soil salinity using halotolerant nitrogen-fixing cyanobacteria Plant and Soil 189 205-211

Apte S K, Reddy B R and Thomas J (1987) Relationship between sodium influx and salt tolerance of nitrogen-fixing cyanobacteria Appl Env Microbiol 53 1934-1939

Apte SK and Haselkorn R (1990) Cloning of salinity stressinduced genes from the salt-tolerant nitrogen-fixing cyanobacterium Anabaena torulosaPlant Molec Biol 15 723-733

Arora PK, Srivastava A and Singh VP (2014) Bacterial degradation of nitrophenols and their derivatives Journal of hazardous materials $26642-59$

Arora PK, Srivastava A and Singh VP (2014) Degradation of 4chloro-3-nitrophenol via a novel intermediate, 4chlororesorcinol by Pseudomonas sp JHN Scientific reports 4

Arora PK, Srivastava A and Singh VP (2014) Novel degradation pathway of 4-chloro-2-aminophenol via 4-chlorocatechol in Burkholderia sp RKJ 800 Environmental Science and Pollution Research 21 2298-2304

Arora PK and Jain RK (2012) Biotransformation of 4-chloro-2nitrophenol into 5-chloro-2-methylbenzoxazole by a marine Bacillus sp strain MW-1 Biodegradation 23 325331

Bajaj A, Pathak A, Mudiam MR, Mayilraj S and Manickam N (2010) Isolation and characterization of a Pseudomonas sp strain IITR01 capable of degrading á endosulfan and endosulfan sulfate Journal of applied microbiology 109 2135-2143

Bala K, Sharma P and Lal R (2010) Sphingobium quisquiliarum sp nov, $\mathrm{P} 25^{\mathrm{T}}$ a hexachlorocyclohexane $(\mathrm{HCH})$ degrading bacterium isolated from $\mathrm{HCH}$ contaminated soil Int J Syst Evol $\backslash$ Microbiol 60 429-433

Balapure KH, Jain K, Chattaraj S, Bhatt NS and Madamwar D (2014) Co-metabolic degradation of diazo dye-Reactive blue 160 by enriched mixed cultures BDN Journal of Hazardous Materials 279 85-95

Balapure K, Jain K, Bhatt N and Madamwar D (2016) Exploring bioremediation strategies to enhance the mineralization of textile industrial wastewater through sequential anaerobicmicroaerophilic process Int Biodeterioration and Biodegradation 106 97-105

Banerjee M, Ballal A and Apte SK (2012a) A novel glutaredoxin domain-containing peroxiredoxin 'Al11541' protects the $\mathrm{N}_{2}$-fixing cyanobacterium Anabaena PCC 7120 from oxidative stress Biochemical J 442 671-680

Banerjee M, Ballal A and Apte SK (2012b) Mn-catalase (Alr0998) protects the photosynthetic, nitrogen-fixing cyanobacterium Anabaena PCC7120 from oxidative stress Env Microbiol 14 2891-2900

Banerjee M, Raghavan P, Ballal A, Rajaram H and Apte SK (2013) "Oxidative stress management in the filamentous, heterocystous, diazotrophiccyanobacterium, Anabaena PCC7120" Photosynth Res 118 59-70

Bashir H, Gangwar R and Mishra S (2015) Differential expression of lignocellulolytic enzymes by Trametes sp OE147 on cellulose and lactose Biochim Biophys Acta-Prot Proteom 1854 1290-1299

Bassalo MC, Liu R and Gill RT (2016) Directed evolution and synthetic biology applications to microbial systems Curr Opin Biotechno 139 126-133

Basu A, Apte SK, and Phale PS (2006) Preferential utilization of aromatic compounds over glucose by Pseudomonas putida CSV86 Appl Environ Microbiol 72 2226-2230

Bedekar PA, Kshirsagar SD, Gholave AR and Govindwar SP (2015) Degradation and detoxification of methylene blue dye adsorbed on water hyacinth in semi continuous anaerobic-aerobic bioreactors by novel microbial consortium-SB RSC Adv 5 99228-99239

Begum SS and Arundhati A (2016) A study of Bioremediation of Methyl Parathion in vitro using Potential Pseudomonas sp isolated from Agricultural Soil, Visakhapatnam, India Int J Curr Microbiol App Sci 5 464-474

Bhagwat AA and Apte SK (1989) Comparative analysis of proteins induced by heat shock, salinity, and osmotic stress in the nitrogen-fixing cyanobacterium Anabaena sp strain L-31 J Bacteriol 171 5187-5189

Chakka D, Gudla R, Madikonda AK, Pandeeti EV, Parthasarathy $S$ and Siddavattam D (2015) The organophosphate degradation ( opd) island borne esterase induced metabolic diversion in $E$ coli and its influence on $p$-nitrophenol degradation J Biol Chem 290 29920-30

Chakraborty R, Wu CH and Hazen TC (2012) Systems biology approach to bioremediation Curr Opin Biotechnol 23 483490 
Chandel AK, Rudravaram R, Rao LV, Ravindra P and Narasu ML (2007) Industrial enzymes in bioindustrial sector development: an Indian perspective Journal of Commercial Biotechnology 13 283-291

Chattaraj S, Johnson J and Madamwar D (2016a) Biotransformation of mixture of dyes by enriched bacterial consortium ASD Desalination and Water treatment 572 $1585-21597$

Chattaraj S, Purohit H, Sharma A, Jadeja N and Madamwar D (2016b) Treatment of Common Effluent Treatment Plant Wastewater in a Sequential Anoxic-Oxic Batch Reactor by Developed Bacterial Consortium VN11 Applied Biochemistry Biotechnology 179 514-529

Chatterjee S, Deb U, Datta S, Walther C and Gupta DK (2017) Common explosives (TNT, RDX, HMX) and their fate in the environment: Emphasizing bioremediation Chemosphere 184 438-451

Chauhan A, Pandey G, Sharma NK, Paul D, Pandey J and Jain RK (2010) p-Nitrophenol degradation via 4-nitrocatechol in Burkholderia sp SJ98 and cloning of some of the lower pathway genes Environmental science and technology $\mathbf{4 4}$ 3435-3441

Chaurasia AK and Apte SK (2009) Overexpression of the groESL operon enhances the heat and salinity stress tolerance of the nitrogen-fixing cyanobacterium Anabaena sp strain PCC7120 Appl Env Microbiol 75 6008-6012

Chaurasia AK, Adhya TK And Apte SK (2013) Engineering bacteria for bioremediation of persistent organochlorine pesticide lindane (gamma-hexachlorocyclohexane) Biores Technol 149 439-445

Chaurasia AK and Apte SK (2011) Improved eco-friendly recombinant Anabaena sp strain PCC7120 with enhanced nitrogen biofertilizer potential Appl Env Microbiol 77 395399

Chhabra M, Mishra S and Sreekrishnan TR (2008) Mediator assisted decolorization/detoxification of reactive/acid dyes and dye mixtures using Cyathus bulleri laccase Appl Biochem Biotechnol 151 587-598

Chhabra M, Mishra S and Sreekrishnan TR (2009) Degradation and detoxification of triarylmethane dyes by laccase/ mediator-assisted laccase of Cyathus bulleriJ Biotechnol 143 69-78

Chhabra M, Mishra S and Sreekrishnan TR (2015a) Combination of chemical and enzymatic treatment for efficient decolorization/degradation of textile effluent: low sludge and high operational stability Biochem Engg J93 17-24

Chhabra M, Mishra S and Sreekrishnan TR (2015b) Immobilized laccase mediated dye decolorization and transformation pathway of Azo Dye Acid Red 27 J Environ Health Sci Engg 13 38-44

Choudhary M, Kumar R, Datta A, Nehra V and Garg N (2017) Bioremediation of Heavy Metals by Microbes InBioremediation of Salt Affected Soils: An Indian Perspective 233-255 Springer International Publishing

Congeevaram S, Dhanarani S, Park J, Dexilin M and Thamaraiselvi K (2007) Biosorption of chromium and nickel by heavy metal resistant fungal and bacterial isolates Journal of hazardous materials 146 270-277

Dadhwal M, Jit S, Kumari H and Lal R (2009) Sphingobium chinhatense sp nov, a hexachlorocyclohexane $(\mathrm{HCH})$ degrading bacterium isolated from an $\mathrm{HCH}$ dump site Int $J$ Syst Evol Microbiol 593 140-3144

Dafale N, Agrawal L , Kapley A, Meshram S, Purohit HJ and Wate S (2010) Selection of indicator bacteria based on screening of $16 \mathrm{~S}$ rDNA metagenomic library from a twostage anoxic-oxic bioreactor system degrading azo dyes Bioresource Technology 101 476-84

Das S and Adhya TK (2015) Degradation of chlorpyrifos in tropical rice soils Journal of environmental management $15236-42$

Dasgupta N, Ranjan S, Mundekkad D, Ramalingam C, Shanker R and Kumar A (2015) Nanotechnology in agro-food: from field to plate Food Research International $69381-400$

Dixit R, Malaviya D, Pandiyan K, Singh U B, Sahu A, Shukla R, Singh B P, Rai J P, Sharma P K, Lade H and Paul D (2015) Bioremediation of heavy metals from soil and aquatic environment: an overview of principles and criteria of fundamental processesSustainability 7 2189-2212

Dogra C, Raina V, Pal R, Suar M, Lal S, Gartemann K H, Holliger C, van der Meer JR and Lal R (2004) Organization of lin genes and IS6100 among different strains of hexachlorocyclohexane-degrading Sphingomonas paucimobilis: Evidence for horizontal gene transfer Journal of Bacteriology 186 2225-2235

Domde P, Kapley A and Purohit HJ (2007) Impact of Bioaugmentation with consortium of bacteria on the remediation of wastewater containing hydrocarbons Environ Sci Pollut R 14 7-11

Dubey KK and Fulekar MH (2012) Chlorpyrifos bioremediation in Pennisetum rhizosphere by a novel potential degrader Stenotrophomonas maltophilia MHF ENV20 World Journal of Microbiology and Biotechnology 28 1715-1725

Dudhagara D R, Rajpara RK, Bhatt JK, Gosai HB, Sachaniya BK and Dave BP (2016) Distribution, sources and ecological risk assessment of PAHs in historically 
contaminated surface sediments at Bhavnagar coast, Gujarat, India Environmental Pollution 213 338-346

Fernandes TA and Apte SK (2000) Differential regulation of nitrogenase activity by ionic and osmotic stresses and permeable sugars in the cyanobacterium Anabaena sp strain L-31 Plant Sci 150 181-189

Gangwar R, Rasool S and Mishra S (2016) Evaluation of cellobiose dehydrogenase and laccase rich culture fluids of Termitomyces sp OE147 for degradation of Reactive blue 21Biotechnol Rep 12 52-61

Garg N, Bieler N, Kenzom T, Chhabra M, Schumacher MA and Mishra S (2012) Cloning, sequence analysis, expression of Cyathus bulleri laccase in Pichia pastoris and characterization of recombinant laccase BMC Biotechnol $1275-87$

Garg R, Srivastava R, Brahma V, Verma L, Karthikeyan S and Sahni G (2016) Biochemical and structural characterization of a novel halotolerant cellulase from soil metagenome Scientific reports6 39634

Goel A, Babu SG and Celin MG (2012) Bioremediation of nitroaromatic compounds

Gogada R, Singh SS, Lunavat SK, Pamarthi MM, Rodrigues A, Vadivelu B, Phanithi PB, Gopala V And Apte SK (2015) Engineered Deinococcus radiodurans $\mathrm{R} 1$ with NiCoT genes for bioremoval of trace cobalt from spent decontamination solutions of nuclear power reactors $\mathrm{Appl}$ Microbiol Biotechnol 99 9203-9213

Goyal P and Bansiwal RK (2017) Environmental Bioremediation: Biodegradation of Xenobiotic Compounds InXenobiotics in the Soil Environment 347-371 Springer International Publishing

Gupta M, Mathur S, Sharma TK, Rana M, Gairola A, Navani NK and Pathania R (2016) A study on metabolic prowess of Pseudomonas sp RPT 52 to degrade imidacloprid, endosulfan and coragen Journal of hazardous materials $301250-258$

Hussain S, Siddique T, Arshad M and Saleem M (2009) Bioremediation and phytoremediation of pesticides: recent advances Critical Reviews in Environmental Science and Technology 39 (843-907)

Iyer R, Iken B and Damania A (2013) A comparison of organophosphate degradation genes and bioremediation applications Environmental microbiology reports 5 787798

Jadeja NB, More RP, Purohit HJ and Kapley A (2014) Metagenomic analysis of oxygenases from activated sludge Bioresour Technol 165 250-256
Jain K, Shah V, Chapla D and Madamwar D (2012) Decolorization and degradation of azo dye - Reactive Violet $5 \mathrm{R}$ by an acclimatized indigenous bacterial mixed cultures-SB4 isolated from anthropogenic dye contaminated soil Journal of Hazardous Materials 213-214 378-386

Jain PK, Gupta VK, Pathak H, Lowry M and Jaroli DP (2010) Characterization of $2 \mathrm{~T}$ engine oil degrading indigenous bacteria, isolated from high altitude (Mussoorie), India World Journal of Microbiology and Biotechnology $261419-$ 1426

Jit S, Dadhwal M, Kumari H, Jindal S, Kaur J, Lata P, Niharika N, Lal D, Garg N, Gupta SK, Sharma P, Bala K, Singh A, Vijgen J, Weber R and Lal R (2011) Evaluation of hexachlorocyclohexane contamination from the last lindane production plant operating in India Environ Sci Pollut Res 18 586-597

Johnson J, Shah B, Jain K, Parmar N, Hinsu A, Patel N, Joshi C and Madamwar D (2016) Draft Genome Sequence of Paenibacillus sp strain DMB5, Acclimatized and Enriched for Catabolizing Anthropogenic Compounds Genome Announc 4 e00211-16

Joshi PK, Swarup A, Maheshwari S, Kumar R and Singh N (2011) Bioremediation of heavy metals in liquid media through fungi isolated from contaminated sources Indian journal of microbiology 51 482-487

Joshi SM, Inamdar SA, Patil SM and Govindwar SP (2013) Molecular assessment of shift in bacterial community in response to Congo Red Int Biodeter Biodegrad 77 18-21

Juwarkar AA (2012) Microbe-assisted phytoremediation for restoration of biodiversity of degraded lands: a sustainable solution Proceedings of the National Academy of Sciences, India Section B: Biological Sciences 82 313-318

Kadam AA, Kamatkar JD, Khandare RV, Jadhav JP and Govindwar SP (2013) Solid state fermentation: Tool for bioremediation of adsorbed textile dyestuff on distillery industry waste-yeast biomass using isolated Bacillus cereus strain EBT1 Environ Sci Pollut Res 20 1009-1020

Kanekar PP, Sarnaik SS, Dautpure PS, Patil VP and Kanekar SP (2014) Bioremediation of nitroexplosive waste waters In Biological Remediation of Explosive Residues Springer International Publishing

Kapley A and Purohit HJ (2009) Diagnosis of treatment efficiency in industrial wastewater treatment plants: A case study at a refinery ETP Environ Sci Technol 43 3789-3795

Kapley A, Liu R, Jadeja NB, Zhang Y, Yang M and Purohit HJ (2015) Shifts in microbial community and its correlation with degradative efficiency in a wastewater treatment plant Appl Biochem Biotechnol 176 2131-2143 
Kapley A, Thierry B and Purohit HJ (2007) Eubacterial diversity of activated biomass from a CETP Research in Microbiology 158 494-500

Kenzom T, Srivastava P and Mishra S (2014) Structural insights into degradation of Reactive Blue 21 by engineered Cyathus bulleri laccase and characterization of the degradation products Appl Environ Microbiol 80 7484-7495

Kenzom T, Srivastava P and Mishra S (2015) Simplified highthroughput screening of $A O X 1$-expressed laccase enzyme in Pichia pastoris Anal Biochem 489 49-51

Kenzom T, Srivastava P and Mishra S (2015) Simplified highthroughput screening of $A O X 1$-expressed laccase enzyme in Pichia pastoris Anal Biochem 489 49-51

Khairnar NP, Kamble VA, Mangoli SH, Apte SK And Misra HS (2007) Involvement of a periplasmic protein kinase in DNA strand break repair and homologous recombination in Escherichia coli Mol Microbiol 65 294-304

Khairnar NP, Misra HS and Apte SK (2003) Pyrroloquinolinequinine synthesized in Escherichia coli by pyrroloquinoline-quinone synthase of Deinococcus radiodurans plays a role beyond mineral phosphate solubilization" Biochem Biophys Res Commun 312303 308

Khan NU, Varma B, Imrana N and Shetty PK (2011) Phytoremediation using an indigenous crop plant (wheat): the uptake of methyl parathion and metabolism of pnitrophenol Indian Journal of Science and Technology 4 17

Khandare RV and Govindwar SP (2015) Phytoremediation of textile dyes and effluents: Current scenario and future prospects Biotechnol Adv 33 1697-1714

Khanna GP, Goyal D and Khanna S (2011) Pyrene biodegradation by Bacillus spp isolated from coal tar-contaminated soil Bioremediation journal 15 12-25

Khardenavis AA, Kapley A and Purohit HJ (2007) Simultaneous nitrification and denitrification by diverse Diaphorobacter sp Appl Microbiol Biotechnol 77 403-409

Khardenavis AA, Kapley A and Purohit HJ (2008) Phenol mediated improved performance of active biomass for treatment of distillery wastewater International Journal of Biodeteroration and Biodegradation 62 38-45

Khardenavis AA, Kapley A and Purohit HJ (2010) Salicylic acid mediated enhanced biological treatment of wastewater Applied Biochemistry and Biotechnology 160 704-18

Kulkarni A, Kadam AA, Kachole MS and Govindwar SP (2014) Lichen Permeliaper lata: A novel system for biodegradation and detoxification of disperse dye Solvent
Red 24 J Hazard Mater 214 461-468

Kulkarni S, Ballal A and Apte SK (2013) Bioprecipitation of uranium from alkaline waste solutions using recombinant Deinococcus radiodurans J Haz Metals 262 853-861

Kulkarni S, Chitra SM, Gupta A, Ballal AA and Apte SK (2016) Interaction of uranium with bacterial cell surface: Inferences from phosphatase mediated uranium precipitation Appl Env Microbiol 824965

Kumar S, Dagar VK, Khasa YP and Kuhad RC (2013) Genetically modified microorganisms (GMOs) for bioremediation In Biotechnology for environmental management and resource recovery 191-218 Springer India

Kumari A, Singh D, Ramaswamy S and Ramanathan G (2017) Structural and functional studies of ferredoxin and oxygenase components of 3-nitrotoluene dioxygenase from Diaphorobacter sp strain DS2 PloS one 12 pe0176398

Kumari R, Subudhi S, Suar M, Dhingra G, Raina V, Dogra C, Lal S, van der Meer JR, Holliger C and Lal R (2002) Cloning and characterization of lin genes responsible for the degradation of hexachlorocyclohexane isomers by Sphingomonas paucimobilis strain B90 Applied and Environmental Microbiology 68 6021-6028

Kundu D, Hazra C and Chaudhari A (2014) Bioremediation of Nitroaromatics (NACs)-Based Explosives: Integrating 'Omics' and Unmined Microbiome Richness In Biological Remediation of Explosive Residues 179-199 Springer International Publishing

Kundu S and Gupta AK (2007) Adsorption characteristics of As (III) from aqueous solution on iron oxide coated cement (IOCC) Journal of Hazardous Materials 142 97-104

Kurade MB, Waghmode TR, Patil SM, Jeon BH and Govindwar SP (2017) Monitoring the gradual biodegradation of dyes in a simulated textile effluent and development of a novel triple layered fixed bed reactor using a bacterium-yeast consortium Chem Eng J 307 1026-1036

Lal R, Dogra C, Malhotra S, Sharma P and Pal R (2006) Diversity, distribution and divergence of lin genes in hexachlorocyclohexane-degrading sphingomonads Trends in Biotechnology 24 121-130

Lal R, Pandey G, Sharma P, Kumari K, Malhotra S, Pandey R, Raina V, Kohler HPE, Holliger C, Jackson C and Oakeshott JG (2010) Biochemistry of Microbial Degradation of Hexachlorocyclohexane and Prospects for Bioremediation Microbiol Mol Biol Rev 74 58-80

Malik DK, Bhatia D and Rathi M (2014) Bacterial Degradation of Some Organophosphate Compounds In Microbial Diversity and Biotechnology in Food Security 531-541 
Springer India

Manoharachary C, Kunwar IK and Rajithasri AB (2014) Advances in applied mycology and fungal biotechnology

Mishra A and Sardar M (2014) Alpha amylase mediated synthesis of gold nanoparticles and their application in the reduction of nitroaromatic pollutants Energy and Environment Focus 3 179-184

Mishra A, Kumari M, Pandey S, Chaudhry V, Gupta KC and Nautiyal CS (2014) Biocatalytic and antimicrobial activities of gold nanoparticles synthesized by Trichoderma sp Bioresource technology 166 235-242

Misra H, Khairnar NP, Kota S, Shrivastava S, Joshi VP and Apte SK (2006) An exonuclease I - sensitive DNA repair pathway in Deinococcus radiodurans: a major determinant of radiation resistance Mol Microbiol 59 1308-1316

Misra HS, Khairnar NP, Barik A, Priyadarshini I, Mohan H and Apte SK (2004) Pyrroloquinoline-quinone : A reactive oxygen species scavenger in bacteria" FEBS Lett 578 2630

Modak A, Bhaumik P and Phale PS (2014) Periplasmic glucosebinding protein from Pseudomonas putida CSV86identification of the glucose-binding pocket by homologymodel-guided site-specific mutagenesis FEBS J 281365 375

Mohanty B, Muduli PR, Behera AT, Mahapatro D, Barik SK, Nag SK, Samal RN and Pattnaik A K (2016) Assessment of petroleum hydrocarbon in a tropical brackish water lagoon: Chilika, India Chemistry and Ecology 32 653-668

Moharikar A, Purohit HJ and Kumar R (2005) Microbial population dynamics at effluent treatment plants $J$ Environ Monit 7 552-558

Mulla SI, Manjunatha TP, Hoskeri RS, Tallur PN and Ninnekar HZ (2011) Biodegradation of 3-Nitrobenzoate by Bacillus flexus strain XJU-4 World Journal of Microbiology and Biotechnology 27 1587-1592

Nagvenkar GS and Ramaiah N (2010) Arsenite tolerance and biotransformation potential in estuarine bacteria Ecotoxicology 19 604-613

Narasimha A, Basu B, Gupta A, Joseph D and Apte SK (2015) Depletion of reduction potential and key energy generation metabolic enzymes underlies tellurite toxicity in Deinococcus radiodurans Proteomics 15 89-97

Narasimha A, Basu B and Apte SK (2016) In situ real time evaluation of radiation-responsive promoters in the extremely radioresistant microbe Deinococcus radiodurans J Biosci 41193-203

Narasimha A, Basu B and Apte SK (2017) Proximity of Radiation
Desiccation Response Motif to the core promoter is essential for basal repression as well as gamma radiationinduced gyrB gene expression in Deinococcus radiodurans Gene 615 8-17

Negi V, Lata P, Sangwan N, Das S, Gupta SK, Rao DLN and Lal R (2014) Draft genome sequence of hexachlorohexane $(\mathrm{HCH})$ degrading Sphingobium lucknowense strain $\mathrm{F}^{\mathrm{T}}$ isolated from the $\mathrm{HCH}$ dumpsite Genome Announcement 2 e00788-14

Nilgiriwala K, Alahari A, Rao AS and Apte SK (2008) Cloning and over-expression of an alkaline phosphatase PhoK from Sphingomonas sp BSAR-1 for uranium bioprecipitation from alkaline solutions Appl Env Microbiol 1784 12561264

Nilgiriwala K, Bihani SC, Das A, Prashar V, Kumar M, Ferrer JL, Apte SK and Hosur MV (2009) Crystallization and preliminary X-ray crystallographic analysis of PhoK, an extracellular alkaline phosphatase from Sphingomonas sp BSAR-1 Acta Cryst F65 917-919

Ningthoujam DS, Sanasam S and Mutum A (2012) Characterization of p-nitrophenol degrading actinomycetes from Hundung limestone deposits in Manipur, India African Journal of Biotechnology 11 10210-10220

Niti C, Sunita S, Kamlesh K and Rakesh K (2013) Bioremediation: an emerging technology for remediation of pesticides Res $J$ Chem Environ 17 88-105

Pailan S and Saha P (2015) Chemotaxis and degradation of organophosphate compound by a novel moderately thermo-halo tolerant Pseudomonas sp strain BUR11: evidence for possible existence of two pathways for degradation Peer J 3 pe 1378

Pal A and Paul AK (2008) Microbial extracellular polymeric substances: central elements in heavy metal bioremediation Indian Journal of Microbiology $\mathbf{4 8} 49$

Pal RR, Khardenavis AA and Purohit HJ (2015) Identification and monitoring of nitrification and denitrification genes in Klebsiella pneumoniae EGD-HP19-C for its ability to perform heterotrophic nitrification and aerobic denitrification Func and Integ Genomics 15 63-76

Paliwal V, Puranik S and Purohit HJ (2012) Integrated perspective for effective bioremediation Appl Biochem and Biotechnol 166 903-924

Paliwal V, Raju SC, Modak A, Phale PS and Purohit HJ (2014) Pseudomonas putida CSV86: A candidate genome for genetic bioaugmentation PLoS One 9 e84000

Panda B, Basu B, Rajaram H and Apte SK (2014) Methyl viologen responsive proteome dynamics of Anabaena sp strain 7120 Proteomics 14 1895-1904 
Panda B, Basu B, Rajaram H and Apte SK (2015) Comparative proteomics of oxidative stress response in three cyanobacterial strains native to Indian paddy fields $J$ Proteomics 127 152-160

Panda B, Basu B, Acharya C, Rajaram H and Apte SK (2017) Proteomic analysis reveals contrasting response to uranium in two nitrogen-fixing Anabaena strains, differentially tolerant to uranium Aquatic Toxicol 182 205-213

Pandeeti EVP and Siddavattam D (2011) Purification and characterization of catechol 1, 2-dioxygenase from Acinetobacter sp DS002 and cloning, sequencing of partial catA gene Indian journal of microbiology 51 312-318

Pandeeti EVP, Chakka D, Pandey JP and Siddavattam D (2011) Indigenous organophosphate-degrading (opd) plasmid pCMS1 of Brevundimonas diminuta is self-transmissible and plays a key role in horizontal mobility of the opd gene Plasmid 65 226-31

Pandeeti EV, Longkumer T, Chakka D, Muthyala VR, Parthasarathy S, Madugundu AK, Ghanta S, Medipally SR, Pantula SC, Yekkala H and Siddavattam D (2013) Multiple mechanisms contribute to lateral transfer of an organophosphate degradation (opd) island in Sphingobium fuliginis ATCC 27551 G3: Genes Genom Genet 2 15411554

Pandey S, Modak A, Phale PS and Bhaumik P (2016) High resolution structures of periplasmic glucose-binding protein of Pseudomonas putida CSV86 reveal structural basis of its substrate specificity J Biol Chem 291 7844-7857

Park JH, Lamb D, Paneerselvam P, Choppala G, Bolan N and Chung JW (2011) Role of organic amendments on enhanced bioremediation of heavy metal (loid) contaminated soils Journal of hazardous materials 185 549-574

Parthasarathy S, Paripatla H, Palmer T and Siddavattam D (2016) Organophosphate Hydrolase is a lipoprotein and interacts with $\mathrm{P}_{\mathrm{i}}$-specific transport system to facilitate growth of Brevudimonas diminuta using OP insecticide as source of phosphate J Biol Chem 291 7774-7785

Patel V, Cheturvedula S and Madamwar D (2012a) Phenanthrene degradation by Pseudoxanthomonas sp DMVP2 isolated from hydrocarbon contaminated sediment of Amlakhadi canal, Gujarat, India Journal of Hazardous Materials 201202 43-51

Patel V and Madamwar D (2013) Biodegradation of phenanthrene in bioaugmented microcosm by consortium ASP developed using coastal sediment of Alang-Sosiya ship breaking yard, Gujarat Marine Pollution Bulletin 74 199-207

Patel V, Munot H, Shouche YS and Madamwar D (2014) Response of bacterial community structure to seasonal fluctuation and anthropogenic pollution on costal water of AlangSosiys ship nreaking yard, Bhavnagar, India Bioresource Technology 161 362-370

Patel V, Munot H, Shah V, Shouche Y and Madamwar D (2015) Taxonomic profiling of bacterial community structure from coastal sediment of Alang-Sosiya shipbreaking yard near Bhavnagar, India Marine Pollution Bulletin 101 736-745

Patil SM, Chandanshive VV, Rane NR, Khandare RV, Watharkar $\mathrm{AD}$ and Govindwar SP (2016) Bioreactor with Ipomoea hererifolia adventitious roots and its endophyte Cladosporium cladosporioids for textile dye degradation Environ Res 146 340-349

Phale PS, Basu A, Majhi PD, Deveryshetty J, Vamsee-Krishna C and Shrivastava R (2007) Metabolic diversity in bacterial degradation of aromatic compounds Omics: a journal of integrative biology 11 252-279

Phale PS, Paliwal V, Raju SC, Modak A and Purohit HJ (2013) Genome sequence of naphthalene-degrading soil bacterium Pseudomonas putida CSV86 Genome announcements 1 e00234-12

Pinjari AB, Pandey JP, Kamireddy S and Siddavattam D (2013) Expression and subcellular localization of organophosphate hydrolase in acephate degrading Pseudomonas sp strain Ind01 and its use as a potential biocatalyst for elimination of organophosphate insecticides Letters in applied microbiology 57 63-68

Purohit HJ, Raje DV, Kapley A, Padmanabhan P and Singh RN (2003a) Genomics tools in environmental impact assessment Env Sci Technol 357A-363A

Purohit HJ, Kapley A, Moharikar A and Narde G (2003b) A novel approach for extraction of PCR-compatible DNA from activated sludge samples collected from different biological effluent treatment plants Journal of Microbiological Methods 52 315-323

Purohit HJ, Kapley A, Khardenavis A, Qureshi A and Dafale NA (2016) Insights in waste management bioprocesses using genomic tools Adv in Appl Microbiol 97 121-170

Qureshi A, Prabu SK and Purohit HJ (2001) Isolation and Characterisation of Pseudomonas strain for degradation of 4-nitrophenol Microbes and Environment 16 49-52

Qureshi A and Purohit HJ (2002) Isolation of bacterial consortia for degradation of p-nitrophenol from agricultural soil Annals in Applied Biology 140 159-162

Qureshi A, Verma V, Kapley A and Purohit HJ (2007) Degradation of 4-nitroaniline by Stenotrophomonas strain HPC 135' International Biodeterioration and Biodegradation $60215-$ 218 
Qureshi A, Mohan M, Kanade GS, Kapley A and Purohit HJ (2009) In situ bioremediation of organochlorine pesticide contaminated microcosm soil and evaluation by gene probe Pest management science 65 798-804

Raghavan PS, Rajaram H and Apte SK (2011) Nitrogen status dependent oxidative stress tolerance conferred by overexpression of MnSOD and FeSOD proteins in Anabaena sp strain PCC7120 Plant Mol Biol 77 407-417

Raghavan P, Rajaram H and Apte SK (2013) N-terminal processing of membrane-targeted MnSOD and formation of multiple active superoxide dismutase dimmers in the nitrogen-fixing cyanobacterium Anabaena sp strain PCC7120" FEBS J $2804827-4838$

Raghavan PS, Rajaram H and Apte SK (2015) Membrane targeting of MnSOD is essential for oxidative stress tolerance of nitrogen fixing cultures of Anabaena sp strain PCC7120 Plant Mol Biol 88 503-514

Rajaram H, Ballal A, Apte SK, Wiegert T and Schumann W (2001) Cloning and characterisation of the major groESL operon from a nitrogen-fixing cyanobacterium Anabaena sp strain L-31 Biochim Biophys Acta : Gene Struct Expr 1519 143146

Rajaram H and Apte SK (2003) Heat-shock response and its contribution to thermotolerance of the nitrogen-fixing cyanobacterium Anabaena sp strain L-31 Arch Microbiol 179 423-429

Rajaram H and Apte SK (2008) Nitrogen status and heat-stressdependent differential expression of cpn60 chaperonin gene influences thermotolerance in the cyanobacetrium Anabaena Microbiology 154 317-325

Rajaram H, Chaurasia AK and Apte SK (2014) Cyanobacterial heat-shock response: role and regulation of molecular chaperones Microbiol 160 647-658

Rangu SS, Muralidharan B, Tripathi SC and Apte SK (2014) Tributyl phosphate biodegradation to butanol and phosphate and utilization by a novel bacterial isolate, Sphingomonas sp strain RSMS Appl Microbiol Biotechnol 98 2289-2296

Rangu SS, Basu B, Muralidharan B, Tripathi SC and Apte SK (2016) Involvement of phosphoesterases in tributyl phosphate degradation in Sphingobium sp RSMS Appl Microbiol Biotechnol 100 461-468

Rao KR, Vipin AV, Hariprasad P, Appaiah KA and Venkateswaran G (2017) Biological detoxification of Aflatoxin B 1 by Bacillus licheniformis CFR1 Food Control 71 234-241

Ray SA and Ray MK (2009) Bioremediation of heavy metal toxicity-with special reference to chromium Al Ameen $J$
Med Sci 2 57-63

Reddy GS, Rafi MM, Kumar SR, Khayalethu N, Rao DM, Manjunatha B, Philip GH and Reddy BR (2016) Optimization study of 2-hydroxyquinoxaline (2-HQ) biodegradation by Ochrobactrum sp HQ1 Biotech 651

Sagarkar S, Bhardwaj P, Storck V, Devers-Lamrani M, MartinLaurent F and Kapley A (2016) s-triazine degrading bacterial isolate Arthrobacter sp AK-YN10, a candidate for bioaugmentation of atrazine contaminated soil Appl Microbiol Biotechnol 100 903-913

Saha SP, Banik SP, Majumder A, Noor A, Biswas K, Hasan N, Banerjee N, Saha P, Das R, Halder S and Parveen S (2014) Bioremediation of Methyl Parathion by Bacterial Strains Isolated from Fresh Vegetables Journal of Environment and Sociobiology 11 43-56

Salony, Mishra S and Bisaria VS (2006) Production and characterization of laccase from Cyathus bulleri and its use in decolourization of recalcitrant textile dyes Appl Microbiol Biotechnol 71 646-653

Salony, Garg N, Baranwal R, Chhabra M, Mishra S, Chaudhuri TK and Bisaria VS (2008) Laccase of Cyathus bulleri: structural, catalytic characterization and expression in Escherichia coli Biochim Biophys Acta-Prot and Proteom 1784 259-268

Saratale RG, Saratale GD, Chang JS and Govindwar SP (2011) Outlook of bacterial decolorization and degradation of azo dyes: a review J Taiwan Inst Chem Eng 42 138-157

Sarkar S, Seenivasan S and Asir RPS (2010) Biodegradation of propargite by Pseudomonas putida, isolated from tea rhizosphere Journal of hazardous materials 174 295-298

Sasikala C, Jiwal S, Rout P and Ramya M (2012) Biodegradation of chlorpyrifos by bacterial consortium isolated from agriculture soil World Journal of Microbiology and Biotechnology 28 1301-1308

Sathyavathi S, Manjula A, Rajendhran J and Gunasekaran P (2014) Extracellular synthesis and characterization of nickel oxide nanoparticles from Microbacterium sp MRS-1 towards bioremediation of nickel electroplating industrial effluent Bioresource technology 165 270-273

Seetharam C, Soundarajan S, Udas AC, Rao AS and Apte SK (2009) Lyophilised, non-viable, recombinant $E$ coli cells for cadmium bioprecipitation and recovery Proc Biochem 44 246-250

Seetharam-Misra C, Appukuttan D, Kantamreddi VSS, Rao AS and Apte SK (2012) Recombinant D. radiodurans cells for bioremediation of heavy metals from acidic/neutral aqueous wastes Bioengineered Bugs 3 44-48 
Seetharam-Misra C, Mukhopadhyay R and Apte SK (2014) Harnessing a radiation inducible promoter of Deinococcus radiodurans for enhanced precipitation of uranium $J$ Biotechnol 189 88-93

Selvakumaran S, Kapley A, Vipin C Kalia and Purohit HJ (2008) Phenotypic and Phylogenic Groups to Evaluate The Diversity of Citrobacter Isolates From Activated Biomass of Effluent Treatment Plants Bioresource Technology 99 1189-1195

Selvakumaran S, Kapley A, Kashyap SM, Daginawala HF, Kalia VC and Purohit HJ (2011) Diversity of aromatic ringhydroxylating dioxygenase gene in Citrobacter Bioresource Technology 102 4600-4609

Sengupta K, Maiti TK and Saha P (2015) Degradation of 4nitrophenol in presence of heavy metals by a halotolerant Bacillus sp strain BUPNP2, having plant growth promoting traits Symbiosis 65 157-163

Shah B, Jain K, Patel N, Pandit R, Patel A, Joshi CG and Madamwar D (2015) Draft genome sequence of Paenibacillus sp Isolated from Alang ship breaking yard which harbors genes for xenobiotic degradation Genome Announcements 3 e00554-15

Shah B, Mohan V, Jain K and Madamwar D (2016a) Microaerophillic symmetric reductive cleavage of reactive azo dye - Ramazole Brilliant Violet 5R by developed consortium VIE6: community synergism Applied Biochemistry and Biotechnology 180 1029-1042

Shah B, Patel A and Madamwar D (2016b) Kinetic modeling and community dynamics of microaerophillic treatment of textile dyes containing effluent by consortium VIE6 Environmental Process Doi: 101007/s40710-016-0156-0

Shah V and Madamwar D (2013a) Community genomics: Isolation, characterization and expression of gene coding for azoreductase International Biodeterioration and Biodegradation 79 1-8

Shah V, Zakrzewski M, Wibberg D, Eikmeyer F, Schlüter A and Madamwar D (2013b) Taxonomic Profiling and Metagenome Analysis of a Microbial Community from a Habitat Contaminated with Industrial Discharges Microbial Ecology 66 533-550

Sharma N, Lavania M and Lal B (2019) microbes and their secondary metabolites agents in bioremediation of hydrocarbon contaminated site. Arch Pet Environ Biotechnol, DOI: 10.29011/2574-7614.100051, 2019

Sharma P, Raina V, Kumari R, Malhotra S, Dogra C, Kumari H, Kohler HPE, Buser HR, Holliger C and Lal R (2006) Haloalkane dehalogenase LinB is responsible for beta- and delta-hexachlorocyclohexane transformation in
Sphingobium indicum B90A Applied and Environmental Microbiology 72 5720-5727

Sharma P, Bala K, Singh A, Vijgen J, Weber R and Lal R (2010) Evaluation of hexachlorocyclohexane contamination from the last lindane production plant operating in India Environmental science and pollution research international 18 586-597

Singare PU (2016) Distribution and risk assessment of suspected endocrine-disrupting pesticides in creek water of Mumbai, India Marine pollution bulletin 102 72-83

Singh A, Shahid M, Srivastava M, Pandey S, Sharma A and Kumar $\mathrm{V}$ (2014) Optimal physical parameters for growth of Trichoderma species at varying $\mathrm{pH}$, temperature and agitation Virol Mycol 3 1-7

Singh A and Prasad SM (2015) Remediation of heavy metal contaminated ecosystem: an overview on technology advancement International Journal of Environmental Science and Technology 12 353-366

Singh B, Kaur J and Singh K (2012) Biodegradation of malathion by Brevibacillus sp strain KB2 and Bacillus cereus strain PU World Journal of Microbiology and Biotechnology 28 1133-1141

Singh DN and Tripathi AK (2013) Coal induced production of a rhamnolipid biosurfactant by Pseudomonas stutzeri, isolated from the formation water of Jharia coalbed Bioresource technology 128 215-221

Singh R, Trivedi VD and Phale PS (2013) Metabolic regulation and chromosomal localization of carbaryl degradation pathway in Pseudomonas sp strains C4, C5 and C6 Arch Microbiol 195 521-535

Sood N, Patle S and Lal B (2010) Bioremediation of acidic oily sludge-contaminated soil by the novel yeast strain Candida digboiensis TERI ASN6 Environmental Science and Pollution Research 17 603-610

Sreenivasulu C, Megharaj M, Venkateswarlu K and Naidu R (2012) Degradation of p-nitrophenol by immobilized cells of Bacillus spp isolated from soil International biodeterioration and biodegradation 68 24-27

Srivastava SK, Yamada R, Ogino C and Kondo A (2013) Biogenic synthesis and characterization of gold nanoparticles by Escherichia coli K12 and its heterogeneous catalysis in degradation of 4-nitrophenol Nanoscale research letters $\mathbf{8}$ 70

Suar M, van der Meer JR, Lawlor K, Holliger C and Lal R (2004) Dynamics of multiple lin gene expression in Sphingomonas paucimobilis $\mathrm{B} 90 \mathrm{~A}$ in response to different hexachlorocyclohexane isomers Appl Environ Microbiol 70 6650-6656 
Suar M, Hauser A, Poiger T, Buser HR, Müller MD, Dogra C, Raina V, Holliger C, van der Meer JR, Lal R and Kohler HP (2005) Enantioselective transformation of alphahexachlorocyclohexane by the dehydrochlorinases LinA1 and LinA2 from the soil bacterium Sphingomonas paucimobilis B90A Appl Environ Microbiol 7 8514-8518

Telke AA, Kadam AA and Govindwar SP (2015) Bacterial enzymes and their role in decolorization of Azo dyes In: Microbial degradation of synthetic dyes in wastewaters (Ed: Singh) pp 149-168 Springer International Publishing, Switzerland

Thangaraj K, Kapley A and Purohit HJ (2008) Characterization of diverse Acinetobacter isolates for utilization of multiple aromatic compounds Bioresource Technology 99 24882494

Tikariha H, Pal RR, Qureshi A, Kapley A and Purohit H J (2016) In silico analysis for prediction of degradative capacity of Pseudomonas putida SF1 Gene 1119 30491-30497

Tiwari J, Naoghare P, Sivanesan S and Bafana A (2017) Biodegradation and detoxification of chloronitroaromatic pollutant by Cupriavidus Bioresource technology 223 184191

Tripathi A, Upadhyay RC and Singh S (2011) Mineralization of mono-nitrophenols by Bjerkandera adusta and Lentinus squarrosulus and their extracellular ligninolytic enzymes Journal of basic microbiology 51 635-649

Trivedi VD, Jangir PK, Sharma R and Phale PS (2016) Insights into functional and evolutionary analysis of carbaryl metabolic pathway from Pseudomonas sp strain C5pp Sci Rep 738430

Ujaoney AK, Potnis A, Mukhopadhyay R and Apte SK (2010) Radiation desiccation response motif (RDRM) like sequences are involved in transcriptional activation of deinococcal $s s b$ gene by ionizing radiation but not by desiccation J Bacteriol 192 5637-5644

Vamsee-Krishna C and Phale PS (2010) Bypassing isophthalate inhibition by modulating glutamate dehydrogenase (GDH): purification and kinetic characterization of NADP-GDHs from isophthalate-degrading Pseudomonas aeruginosa strain PP4 and Acinetobacter lwoffii strain ISP4 J Bacteriol 192 801-806

Varjani SJ and Upasani VN (2013) Comparative studies on bacterial consortia for hydrocarbon degradation Int J Innov Res Sci Eng Technol 2 5377-5383

Varjani SJ and Upasani VN (2016) Biodegradation of petroleum hydrocarbons by oleophilic strain of Pseudomonas aeruginosa NCIM 5514 Bioresource technology 222 195201

Varjani SJ (2017) Microbial degradation of petroleum hydrocarbons Bioresource technology 223 277-286

Vats A and Mishra S (2017) Decolorization of complex dyes and textile effluent by extracellular enzymes of Cyathus bulleri cultivated on agro-residues/domestic wastes and proposed pathway of degradation of Kiton blue A and reactive orange 16 Environ Sci Pollut Res 24 11650-11662

Venkata S, Mohan P, Suresh B, Naresh K, Velvizhi G and Madamwar D (2012) Acid azo dye remediation in anoxicaerobic-anoxic microenvironment under period discontinous batch operation: Bio-electro kinetics and microbial inventory Bioresour Technol 119 362-372

Verma H, Kumar R, Oldach P, Sangwan N, Khurana JP, Gilbert JA and Lal R (2014) Comparative genomic analysis of nine Sphingobium strains: insights into their evolution and hexachlorocyclohexane $(\mathrm{HCH})$ degradation pathways $B M C$ Genomics 151014

Verma V, Raju SC, Kapley A, Kalia VC, Kanade GS, Daginawala HF and Purohit HJ (2011) Degradative potential of Stenotrophomonas strain HPC383 having genes homologous to dmp operon Bioresource technology 102 3227-3233

Wasi S, Tabrez S and Ahmad M (2011) Suitability of immobilized Pseudomonas fluorescens SM1 strain for remediation of phenols, heavy metals, and pesticides from water Water Air and Soil Pollution 220 89-99

Yadav TC, Khardenavis AA and Kapley A (2014) Shifts in microbial community in response to dissolved oxygen levels in activated sludge Bioresour Technol 165 257-264 